Dean Phillip Bell

\title{
The Impact of the Reformation on Early Modern German Jewry
}

\author{
Politics, Community, and Religion
}

\section{Introduction}

It seems somewhat unnecessary by now to state candidly that the Reformation, at least as traditionally understood, never occurred. While something most assuredly happened in Germany in the sixteenth century, it is impossible to conceive of what that something was absent a discussion of what came before and what came after. In other words, any inquiry into the 'Reformation' calls for coverage of a daunting range of topics, personalities, and localities.

We do know that anniversaries, such as the one commemorating the $500^{\text {th }}$ anniversary of Luther's 95 Theses, are historical constructs. As Robert Scribner, the renowned historian of the German Reformation, has reminded us in a slender but provocative book on another anniversary - the occasion of the $500^{\text {th }}$ anniversary of the birth of Martin Luther - for most of us, the Reformation began when Luther brazenly, if rather commonly, posted his 95 Theses on the door of the Castle Church in Wittenberg in 1517. But, Scribner cautions,

\begin{abstract}
Despite much scholarly debate, it remains uncertain whether the theses were ever posted; the real significance of the alleged incident resided in the fact that much later in the sixteenth century a myth was created that this was how 'the Reformation' began. This myth is typical of a number of myths about the Reformation. It involves a teleological view of history, an arrangement from hindsight of the course of events into an inevitable pattern in which no other outcome is envisaged than 'the Reformation' as later ages understood it. ${ }^{1}$
\end{abstract}

Ruing what he deems an excessive focus on Luther, Scribner points to the complexity of a protracted historical process that better reflects the Reformation as a historical phenomenon. ${ }^{2}$ For Scribner and for us, however, such myths and historical constructions provide a valuable opportunity to question handed-down

1 Robert W. Scribner, The German Reformation (Atlantic Highlands, NJ: Humanities Press, 1986), 1.

2 Ibid., 2.

Ә OpenAccess. (C) 2020 Aue-Ben-David et al., published by De Gruyter. (cc))BY This work is licensed under the Creative Commons Attribution 4.0 International. https://doi.org/10.1515/9783110664713-003 
assumptions and to seek a broader context for understanding both the past and present.

Like other scholars, Scribner observed that the term 'Reformation' was itself somewhat anachronistic in the sixteenth century. It was used in the modern sense to describe a period in Church history only beginning in the seventeenth century under particularly polemical circumstances, eventually becoming a self-legitimating mantra for confessional churches in the nineteenth and twentieth centuries. ${ }^{3}$ Still, while the Reformation in the modern sense was a construction, the term Reformation did have important currency in the late medieval period and the sixteenth century in three specific contexts: first, as a legal code; second, as a restructuring of a university curriculum; and finally, as internal reform of the church (coming closest here to later Reformation notions). The term also carried a popular sense, almost of apocalyptic dimensions, of ushering in a great change. ${ }^{4}$ In this regard, there is some overlap with more recent discussions of Confessionalization (see below).

Recognizing the complexity of something called the Reformation, as well as the need to take a long view of events and developments, including earlier trends (which some scholars suggest we seek already back in the twelfth century) and later developments, beginning with Confessionalization, we have a remarkable opportunity to (re)consider developments within German Jewry during the Reformation period.

Jewish historiography has balanced its treatment of the Reformation and the Jews between two poles, reflected in the varying interpretations of Luther as the embodiment of the German lauter, pure, ${ }^{5}$ or the Hebrew lo-tahor, impure. ${ }^{6}$ On the one hand, the Reformation is recognized as a decisive event that led to increasingly bitter and abusive theological and political, and in some cases even 'racial,' discrimination and concomitant expulsion from various cities and territories throughout central Europe. Indeed, according to some scholars,

3 Ibid., 4.

4 Ibid.

5 "Light” in Hayyim Hillel Ben-Sasson's translation; see Haim Hillel Ben-Sasson, "The Reformation in Contemporary Jewish Eyes," The Israel Academy of Sciences and Humanities Proceedings 4:12 (1970): 239-326.

6 See ibid., 272 and n. 96, and 288; see also Joseph M. Davis on Eliezer Eilburg; as Davis points out, an anonymous polemical treatise played with Luther's first name as well, since 'martina' was the Aramaic word for clay, it could note that "In 1520 a priest named Martin arose [...] and his name proves that he is common clay [...]”; Joseph M. Davis, “The 'Ten Questions' of Eliezer Eilburg,” Hebrew Union College Annual 80 (January, 2009): 173-244, here at 229. 
the reformers' attitude towards the Jews paved the way for the centuries-later annihilation of European Jewry - the Sonderweg theory. ${ }^{7}$

On the other hand, in the view of other scholars, the Reformation ushered in a dissolution of the homogeneous and all-powerful church and led to the eventual removal of anti-Jewish motifs such as host desecration and ritual murder. Further, the Reformation, with its emphasis on the Hebrew Bible and the refashioning of Protestants as the ancient Israelites and Christian cities as new Zions, by the end of the sixteenth century led to an unprecedented degree of toleration of Jews through the reception of Roman Law and the interest in Hebrew language, the Hebrew Bible, and Jewish customs. Jews, too, felt the burning apocalyptic sense of the age, envisioning their own redemption and the beginning of a messianic era. Moreover, many scholars suggest that the Reformation, with its alleged Protestant Ethic, led to the economic reintegration of European Jewry by the end of the sixteenth century. ${ }^{8}$

Well representing an older stream of historical interpretation - one which noted the ill treatment of the Jews but also their essential Otherness - the towering nineteenth-century Jewish historian Heinrich Graetz (1817-1891) once wrote that,

It is astonishing, yet not astonishing, that the surging movement, the convulsive heaving that shook the Christian world from pole to pole in the first quarter of the sixteenth century scarcely touched the inner life of the Jews [...] Having had no 'Middle Ages,' they needed no new epoch. They needed no regeneration, they had no immoral course of life to redress, no cankering corruption to cure, no dam to raise against the insolence and rapacity of their spiritual guides. They had not so much rubbish to clear away [...]. ${ }^{9}$

7 See Salo Wittmayer Baron, A Social and Religious History of the Jews, vol. 13 ( $2^{\text {nd }}$ ed.) (New York: Columbia University Press, 1969), 217: "Hence it was mainly in the territory of the Holy Roman Empire that the great drama of the Reformation immediately affected many Jewish communities and constituted a major factor in the subsequent destinies of the Jewish people, down to the Nazi era and beyond.”

8 According to Baron, for example, "At the same time, the chronologically preceding influences of the Protestant Reformation upon Jewish history had to be treated in a subsequent chapter as an integral factor in the transformation of modern Europe and the ensuing emancipation of the Jews” ; Salo W. Baron, "Emphases in Jewish History,” in History and Jewish Historians: Essays and Addresses (Philadelphia: Jewish Publication Society of America, 1964): 65-89, here at 69. Baron argues that, "[...] in the long run, the Reformation contributed to the religious diversification, and subsequently to the growing secularization, of Europe. In time, these forces were bound to affect deeply also the position of Jews in the modern world"; Baron, A Social and Religious History of the Jews, vol. 13, 206.

9 Heinrich Graetz, History of the Jews, vol. IV (Philadelphia: Jewish Publication Society of America, 1956 [orig. 1894]), 477. 
One of the few, early scholars to examine the contemporary Jewish view of the Reformation was Haim Hillel Ben-Sasson (1914-1977). As Ben-Sasson noted at the beginning of one of his by now dated, but still important and landmark essays:

Essentially this conflict within the Christian community no doubt left the Jew in the role of an outside observer. Nevertheless, there were some Jews who regarded themselves as involved in this struggle, whether through force of circumstances, or as a result of certain illusions that they chose to nurture. Whatever the cause, it can hardly be denied that many of the phenomena of the Christian controversy and attendant problems had a definite bearing upon Jewish life and thought. ${ }^{10}$

Ben-Sasson identified the fact, a bit begrudgingly perhaps, that the Reformation clearly had resonance in Jewish life and thought. In the years since his research, the regular rejection of traditional historiographical emphases on intellectual accomplishments and persecution, in favor of a more nuanced and frequently less pristine, harmonious, and isolated society than was once imagined has fruitfully complicated our image of early modern German Jewry.

Thus, an abundance of recent studies have added significant depth to our understanding of the position of Jews and the Jewish community in the larger non-Jewish world and have pointed to remarkably rich social interactions and intellectual engagements between Jews and Christians. Yet historians often remain reticent to explore the extent to which the broader changes associated with the Reformation affected the social and communal aspects of 'internal' Jewish life. This is true to such a degree that we may even allow for the standard bifurcation of 'internal' and 'external,' or even the segregation of what were once distinct fields of inquiry such as social, political, intellectual, economic, and cultural history. ${ }^{11}$ The representation of Jews and Judaism, the accomplishments and activities of some Jewish scholars, and even the impact of Judaism and Jews on the

10 Ben-Sasson, "The Reformation in Contemporary Jewish Eyes," 239. In another article, BenSasson reflected that, "On closer inspection Jewish culture in Germany turns out to be much more receptive to nonnative elements, more variegated, than current views about it would allow"; Hayyim Hillel Ben-Sasson, "Jewish-Christian Disputation in the Setting of Humanism and Reformation in the German Empire,” Harvard Theological Review 59 (1966): 369-90, here at 369.

11 There are, however, a number of contributions to this discussion, including Dean Phillip Bell, Jewish Identity in Early Modern Germany: Memory, Power and Community (Aldershot: Ashgate Publishers, 2007); Debra Kaplan, Beyond Expulsion: Jews, Christians, and Reformation Strasbourg (Stanford, CA: Stanford University Press, 2011); and Rachel L. Greenblatt, To Tell Their Children: Jewish Communal Memory in Early Modern Prague (Stanford, CA: Stanford University Press, 2014). 
Reformation have received much attention in scholarship and continue to garner interest from Jewish and Christian scholars alike. Less attention, however, has been paid to other aspects of the Reformation and the Jews. A recent exception is the book Jews, Judaism, and the Reformation in Sixteenth-Century Germany, which appeared in 2006. The volume attempts to place the issue of the Reformation into conversation with the topic of Judaism and the Jews through the exploration of a longer historical and intellectual context and the consideration of a broad range of reformers' (beyond Luther's) attitudes towards Judaism and the Jews. Particularly helpful for present purposes, it also probed the impact of the Reformation on Jewish intellectual, legal, religious, and communal developments. ${ }^{12}$

The short shrift paid until recently to the internal effects of the Reformation on the Jews is undoubtedly due, at least in part, to the dearth of sources available to scholars. Plausibly, too, the focus of Reformation studies and the assumption - among Christian and Jewish scholars alike - that Jewish and Christian interaction was quite limited, likely also contributed to this neglect. A range of diverse studies, however, has shown that the multi-faceted early modern German Jewish communities were closely linked to a longer and broader Jewish tradition, and that they variously engaged with, borrowed from, and at times rejected the momentous changes sparked by the Reformation. ${ }^{13}$

This topic calls for some caution. While we have certainly witnessed a broadening of perspective and historical recalibration (as demonstrated in some of the scholarship referenced in the notes), one might argue that in our recent rush to repudiate the older lachrymose view of Jewish history we may be going too far in the other direction, running the risk of over-emphasizing notions of convivencia and acculturation. The balance of this essay, therefore, will rehearse some of the valuable opportunities to contextualize early modern German Jewish developments in the era of Reformation, but also remind us that Jewish communal his-

12 Dean Phillip Bell and Stephen G. Burnett, eds., Jews, Judaism, and the Reformation in Sixteenth-Century Germany (Leiden and Boston: Brill, 2006).

13 Traditionally, the Reformation has been interpreted to have had little direct impact on the religion of sixteenth-century Jews. As one early twentieth-century scholar wrote, "Despite the spread of Luther's writings among the Jews, it left the spirit of the people untouched, and only in isolated instances did conversions to Lutheranism occur; Luther himself complained that Jews read his works only to refute them": Louis Israel Newman, Jewish Influences on Christian Reform Movements (New York: Columbia University Press, 1925), 629. The same author notes, however, that the Reformation did have a significant impact on later Jewish history, ushering in a new era for European Jewry and paving the way and serving as a model for the nineteenth-century Reform movement within Judaism (ibid.). 
tory and development were also marked by boundaries and unique concerns as well as a connection with longer-term internal trajectories and discourse.

\section{The Politics of Jewish and Christian Relations}

I begin with the question of whether the Reformation affected Jewish and Christian relations, ${ }^{14}$ which I consider through policies on Jewish settlement and expulsion. There were numerous expulsions of Jews in German lands - in cities and territories - in the later Middle Ages and on the eve of the Reformation. ${ }^{15}$ The late medieval expulsions reflected a number of important political, econom-

14 There is a large and ever growing literature on many aspects of Jewish and Christian relations in the Reformation period. Among the more recent works, consider the following: Miriam Bodian, "The Reformation and the Jews," in Rethinking European Jewish History, eds. Jeremy Cohen and Moshe Rosman (Oxford: Littman Library of Jewish Civilization, 2009): 112-32. Regarding the Reformation and the Jews in a more traditional religious and intellectual context, see, for example, Achim Detmers, Reformation und Judentum: Israel-Lehren und Einstellungen zum Judentum von Luther bis zum frühen Calvin (Stuttgart: Kohlhammer, 2001); Avner Shamir, Christian Conceptions of Jewish Books: The Pfefferkorn Affair (Copenhagen and Lancaster: Museum Tuscalanum Press and Gazelle, 2011); David H. Price, Johannes Reuchlin and the Campaign to Destroy Jewish Books (Oxford and New York: Oxford University Press, 2011); Debra Kaplan, "Sharing Conversations: A Jewish Polemic against Martin Luther," Archiv für Reformationsgeschichte 103 (2012): 41-63; Brooks Schramm and Kirsi I. Stjerna, Martin Luther, the Bible and the Jewish People: A Reader (Minneapolis: Fortress Press, 2012); Yaacov Deutsch, Judaism in Christian Eyes: Early Modern Descriptions of Jews and Judaism (Oxford and New York: Oxford University Press, 2012); Stephen G. Burnett, Christian Hebraism in the Reformation Era (1500-1660): Authors, Books, and the Transmission of Jewish Learning (Leiden and Boston: Brill, 2012); and, Jewish Books and their Readers: Aspects of the Intellectual Life of Christians and Jews in Early Modern Europe, eds. Scott Mandelbrote and Joanna Weinberg (Leiden and Boston: Brill, 2016). On Luther and the Jews there is a vast literature by now. See, for example, Thomas Kaufmann, Luther's Jews: A Journey into Anti-Semitism, trans. Lesley Sharpe and Jeremy Noakes (Oxford and New York: Oxford University Press, 2017).

15 Among the significant regional expulsions we can number: The Palatinate (1390/91); Thuringia (1401); Austria (1420/21); Breisgau (1421); Bavaria-Munich (1442); Bavaria-Landshut (1450); Mecklenburg/Pomerania (1492); Carniola (1496); and Styria (1496). In the first half of the sixteenth century, regional expulsions occurred in a number of areas, including Brandenburg (1510); Alsace (ca. 1520), and Saxony (1540). The regional expulsions might also include large archbishoprics, such as Cologne (1429), Mainz (1470), and Magdeburg (1493), or clusters of cities, as throughout Bohemia in 1454. During the fifteenth century, Jews were expelled from numerous German cities, such as Vienna (1421), Cologne (1424), Augsburg (1438/40), Mainz (1438 and 1470), Munich (1442), Würzburg (1450), Breslau (1453/54), Erfurt (1453/54), Hildesheim (1457), Bamberg (1478), Salzburg (1498), Nuremburg (1499), Ulm (1499), Nördlingen (1504), Regensburg (1519), and Rothenburg ob der Tauber (1520). 
ic, and social changes in the German commune, including discussions about the nature of ministry and political power, for example. In addition, the religious changes prior to the Reformation, which led to a sacralization of German communal life, help to explain the growing marginalization of the Jews in late medieval German society. The Reformation continued this marginalization, while also revamping the terrain in some crucial ways.

Jewish life in early modern Germany was subsumed under different layers of experience and authority. While Jews lived in specific cities, towns, or villages, they were also subject to territorial and imperial conditions. These territorial realities - which were themselves influenced by the Reformation - could affect Jewish settlement and Jewry law, at times creating opportunities and at times leading to restriction or expulsion. In such cases, Jewish relations with the emperor and the imperial court could be pivotal. Jewish delegates made their way to the emperor and to imperial diets to plead the case of their communities and to offer much-needed financial support. The famous Shtadlan, Josel of Rosheim (1476-1554), came, in time, to side with the Catholic emperor. Ben-Sasson attributes this to his "conservative turn of mind and social ideology," also related to general political conditions. ${ }^{17}$ According to Josel:

At all times - as we have now seen with our own eyes in the case of a people that has established a new faith, with all kinds of leniencies in order to cast off the yoke. And their aim was to set upon us and annihilate the people of Israel by various and harsh legal measures and massacres. But God, seeing the affliction of His people, sent His angel, merciful kings, to give power and might to his majesty, the Emperor Charles - long may he live! - that he might prevail over them on many occasions, breaking their covenant and voiding their conspiracy. [...] And by a miracle he triumphed and saved the people of Israel from the hands of the new faith established by the priest called Martin Luther, an unclean man, who intended to destroy and slay all the Jews, both young and old. Blessed be the Lord, who foiled his counsel and frustrated his designs and allowed us to behold His vengeance and many salvations to this day. ${ }^{18}$

The status of the Jews in Hesse provides an intriguing prism through which to look at discussions of toleration and expulsion of the Jews in a Reformation context. In the 1530s, the Landgrave Philip sought to clarify the position of the Jews living in his territory. Eminently practical in his economics and often his politics as well, Philip granted the Jews limited protection while turning to reforming

16 Ben-Sasson, “The Reformation in Contemporary Jewish Eyes," 293.

17 Sefer ha-Miknah, translated in Ben-Sasson, ibid., 291.

18 Joseph of Rosheim, Sefer ha-Miknah, ed. Hava Fraenkel-Goldschmidt (Jerusalem: Mekizei Nirdamim, 1970), 73-4; translated in Ben-Sasson, “The Reformation," 291. The italics belong to Ben-Sasson. 
theologians, especially Martin Bucer (1491-1551), for advice on what position to adopt on the Jewish question. ${ }^{19}$ Continuing a long line of Christian analysis, Bucer distinguished between the biblical Israel of the elect (or of the spirit) and empirical Judaism (or corporeal Israel), providing numerous historical examples of rulers expelling the Jews. Philip, however, cast the Jews as a noble race, who might reestablish their covenant with God. Along the way, they might also prove to be of financial benefit to the territory.

Underlying these various positions on the fate of the Jews of Hesse, one discerns several core 'Reformation' issues. First, the debate over true religious identity and the notion of ad fontes, in which different religious groups strove to claim historical, and thereby a certain spiritual, legitimacy and primacy. This battle would continue at the end of the sixteenth century, through Confessionalization, as Catholics and Protestants debated the calendar and Jews such as David Gans (1541-1613) attempted to make Jews into historical actors, with a role in shaping the past and present. ${ }^{20}$ Second, we find a close relationship between matters of state and religious tolerance (not toleration in the modern sense), with an emphasis on moral behavior and a certain Godly law that even Josel referenced. ${ }^{21}$ Third, we see the reality, veiled in criticism, of religious

19 On Bucer and the Jews, see Timothy J. Wengert, "Bucer, the Jews, and Judaism," in Bell and Burnett, eds., Jews, Judaism, and the Reformation, 137-69. See also Dean Phillip Bell, "Jewish Settlement, Politics, and the Reformation," in ibid., 421-50. See also Carl Cohen, "Martin Bucer and his Influence on the Jewish Situation," Leo Baeck Institute Year Book 13 (1968): 93-101; R. Gerald Hobbs, "Martin Bucer et les Juifs," in Martin Bucer and Sixteenth Century Europe: Actes du colloque de (28-31 août 1991), eds. Christian Krieger and Marc Lienhard (Leiden and New York: Brill, 1993): 681-89; Wilhelm Maurer, "Butzer und die Judenfrage in Hessen," in Kirche und Geschichte, vol. II, eds. Ernst Wilhelm Kohls and Gerhard Müller (Göttingen: Vandenhoeck \& Ruprecht, 1970): 347-65; and Willem Nijenhuis, "A Remarkable Historical Argumentation in Bucer's 'Judenratschlag'," and "Bucer and the Jews," in idem, Ecclesia Reformata: Studies on the Reformation (Leiden and New York: Brill, 1972), 23-37, 38-72. More recently, see Christoph Strohm, "Martin Bucer und die Juden," in Protestantismus, Antijudaismus, Antisemitismus: Konvergenzen und Konfrontationen in ihren Kontexten, eds. Dorothea Wendebourg, Andreas Stegmann, and Martin Ohst (Tübingen: Mohr Siebeck, 2017): 79-96; and Görge K. Hasselhoff, "Ein ehemaliger Dominikaner als Reformator: Martin Bucer und die Juden,” in Dominikaner und Juden: Personen, Konflikte und Perspektiven vom 13. bis zum 20. Jahrhundert, eds. Elias H. Füllenbach and Gianfranco Miletto (Berlin and Boston: de Gruyter, 2015): 349-73.

20 See Dean Phillip Bell, "Jewish and Christian Historiography in the Sixteenth Century: A Comparison of Sebastian Münster and David Gans,” in God's Word for Our World: In Honor of Simon John DeVries, eds. J. Harold Ellens, Deborah L. Ellens, Rolf P. Knierim, and Isaac Kalimi, vol. 2 (London: Continuum International Publishing Group, 2004): 141-58.

21 In his "Article and Ordinance" of 1530, Josel refers to "godly law" when discussing what happens when a Christian has a complaint against a Jew; see Ludwig Feilchenfeld, Rabbi von Rosheim: Ein Beitrag zur Geschichte der Juden in Deutschland im Reformationszeitalter (Strasbourg: 
change. While it is true that late medieval Jews grappled with informers and apostasy, Josel raised the discussion of these groups to an entirely new level, reflecting many of the debates current within the Christian world of conversion between Christian religions, particularly significant after the middle of the sixteenth century. ${ }^{22}$ At the same time, Josel noted that Bucer's writings had the effect of stirring up the common people and inciting them against the Jews. ${ }^{23}$ In their defense, Josel insisted that Jews were the true Chosen People of God and

J.H.E. Heitz, 1898), 156. Later on he notes, "We are also men, created by God the almighty to live on the earth, to live and deal among them and with them" (ibid., 157).

22 Elisheva Carlebach has noted that in his depiction of the expulsion of the Jews from Regensburg Josel's emphasis on apostates as a primary hostile Other deflects responsibility for oppression of the Jews from territorial rulers to an internal malefactor; Elisheva Carlebach, "Between History and Myth: The Regensburg Expulsion in Josel of Rosheim's Sefer Ha-Miknah,” in Jewish History and Jewish Memory: Essays in Honor of Yosef Hayim Yerushalmi, eds. Elisheva Carlebach, John M. Efron, and David N. Myers (Hanover, NH: Brandeis University Press, 1998): $40-53$, here at 46. This is Yosef Hayim Yerushalmi's notion of the "profound internalization and concomitant glorification of the myth of the royal alliance" amongst Jews noted by David Myers; see David N. Myers, "Of Marranos and Memory: Yosef Hayim Yerushalmi and the Writing of Jewish History," in Jewish History and Jewish Memory, 1-21, here at 6. The work of Jacob Katz and other historians forced a re-evaluation of the once perceived monolithic nature of Jewish religious belief and community boundaries. Katz articulated concepts he labeled "halakhic flexibility" and the "semi-neutral society" that revealed a Jewish society able to encompass degrees of deviation from rabbinic or communal norms in pre-modern times. Evidence for such divergence can be found in a range of texts. Yom-Tov Lipmann Mühlhausen's polemical Sefer ha-Nizzahon, to give one example, served both to argue against Christian theology as well as Jews who deviated and apostatized from Judaism; see Israel Jacob Yuval, "Kabbalisten, Ketzer und Polemiker: Das kulturelle Umfeld des Sefer ha-Nizachon von Lipman Mühlhausen," in Mysticism, Magic and Kabbalah in Ashkenazic Judaism, eds. Karl Erich Grözinger and Joseph Dan (Berlin: de Gruyter, 1995): 155-71, here at 161, 170. Mühlhausen addresses his polemic to Christians, heretics, and various sectarians. See Yom-Tov Lipmann Mühlhausen, Sefer ha-Nitsahon, ed. Frank Talmage (Jerusalem: Merkaz Dinur, 1984) [Hebrew], especially 20-22 in the editor's introduction, as well as the first page of the author's introductory remarks (47). See also Joseph M. Davis, "Drawing the Line: Views of Jewish Heresy and Belief Among Medieval and Early Modern Ashkenazic Jews," in Rabbinic Culture and Its Critics: Jewish Authority, Dissent, and Heresy in Medieval and Early Modern Times, eds. Daniel Frank and Matt Goldish (Detroit: Wayne State University Press, 2008): 161-94.

23 Pointing to the events on the streets of Friedburg where "a poor Jew was struck and his life taken, while the perpetrators jeered: 'see, Jew, the writings of Bucer say that your goods should be taken and distributed among the poor." Joseph of Rosheim, Trostschrift, in Joseph of Rosheim: Historical Writings, ed. Hava Fraenkel-Goldschmidt (Jerusalem: Magnes Press, 1996), $328-49$, here at 331 [German]. 
stressed the continuity of the Jewish people. ${ }^{24}$ Josel thus placed the Jews and Judaism squarely within the confines of Reformation debates, but he did so by maintaining their exceptionalism.

\section{Confessionalization and the Jews: A Long View of the Reformation}

Taking a long view of the Reformation, Confessionalization - namely, the social and theological process of denominational identity construction during and after the Reformation - is a highly charged concept that has been much discussed in recent historiography. It is worth considering in the context of German Jewry. ${ }^{25}$

24 In his reading of many of the historical cases of expulsion of the Jews, Josel located the machinations of apostates and informers. See Dean Phillip Bell, Sacred Communities: Jewish and Christian Identities in Fifteenth-Century Germany (Boston and Leiden: Brill, 2001), chapter 8 .

25 Wolfgang Reinhard, a central scholar of Confessionalization, has provided a rich overview in his assessment of Catholic Confessionalization. Reinhard argues that Confessionalization was caused by religious innovation and the origin of and competition between more churches with absolute claims. He divides the forms of Confessionalization between processes and institutions. See also Wolfgang Reinhard, "Zwang zur Konfessionalisierung? Prolegomena zu einer Theorie des konfessionellen Zeitalters,” Zeitschrift für historische Forschung 10 (1983): 257-77, here at 258, 263; and idem, "Gegenreformation als Modernisierung? Prolegomena zu einer Theorie des konfessionelles Zeitalters," Archiv für Reformationsgeschichte 68 (1977): 226-52. See also the work of Heinz Schilling, including: "Die Konfessionalisierung im Reich," Historische Zeitschrift 246 (1988): 1-45; and, "Confessionalization: Historical and Scholarly Perspectives of a Comparative and Interdisciplinary Paradigm," in Confessionalization in Europe, 15551700: Essays in Honor and Memory of Bodo Nischan, eds. John M. Headley, Hans J. Hillerbrand, and Anthony J. Paplas (Aldershot: Ashgate, 2004), 21-35. On Confessionalization and the Jews, see Gerhard Lauer, "Die Konfessionalisierung des Judentums: Zum Prozess der religiösen Ausdifferenzierung im Judentum am Übergang zur Neuzeit," in Interkonfessionalität - Transkonfessionalität - binnenkonfessionelle Pluralität: Neue Forschungen zur Konfessionalisierungsthese, eds. Kaspar von Greyerz, Manfred Jakubowski-Tiessen, Thomas Kaufmann, and Hartmut Lehmann (Gütersloh: Gütersloher Verlaghaus, 2003): 250 - 83. See also Dean Phillip Bell, "Confessionalization and Social Discipline in Early Modern Germany: A Jewish Perspective," in Politics and Reformations: Studies in Honor of Thomas A. Brady, Jr., eds. Peter Wallace, Peter Starenko, Michael Printy, and Christopher Ocker (Leiden and Boston: Brill, 2007): 345-72, and idem, "Polemics of Confessionalization: Depictions of Jews and Jesuits in Early Modern Germany," in "The Tragic Couple:' Encounters between Jews and Jesuits, eds. James Bernauer and Robert Maryks (Leiden and Boston: Brill, 2014): 65-86; Michael Driedger, "The Intensification of Religious Commitment: Jews, Anabaptists, Radical Reform, and Confessionalization,” in Bell and Burnett, eds., Jews, Judaism, and the Reformation in Sixteenth-Century Germany, 269-99; and Yosef Ka- 
Four central, and overlapping, topics raised by the Confessionalization paradigm resonate with what we now know about early modern German Jewry: questions of conformity (orthodoxy?) and the role of customs; the marginalization and eradication of dissident behavior; the formalization and monopolization of education; and, communal or institutional (re)organization.

Early modern German Jewish customs books sought to codify local and regional customs, especially as regional identities developed and as German Jews responded to a broader pull in early modern Judaism towards codification. The tension between more universal codes and particular local practices and scholars highlights nicely what appears to be a period of transition in which standards of belief and practice were coalescing. Early modern Ashkenazic authorities initially had distinctly mixed responses to the codification reflected in the Shulhan Arukh. Hayyim ben Bezalel (c. 1520 -1588) grumbled that such codification complicated the problem by which "there are many uneducated who are not worried about the ancient writings, do not even understand them, and in the meantime forget the Torah." ${ }^{26}$ Initially hostile Ashkenazic reactions to codifica$\operatorname{tion}^{27}$ gave way, within a generation or so, to an engagement with, if not complete embrace, of Joseph Karo's (1488-1575) and Moses Isserles's (1530-1572) codes of Jewish law. ${ }^{28}$ Joseph Davis has argued that, despite the ongoing production of collections of local customs, the synods of late sixteenth-century German Jewry "gave evidence of the new, clearer sense of forming a single community."29 Ironically, however, both localized customs and broader codification could create greater uniformity, albeit at different levels and in different ways.

plan, "Between Christianity and Judaism in Early Modern Europe: The Confessionalization Process of the Western Sephardi Diaspora," in Judaism, Christianity, and Islam in the Course of History: Exchange and Conflicts, eds. Lothar Gall and Dietmar Willoweit (Munich: R. Oldenbourg, 2011): 307-41.

26 Moritz Güdemann, Quellenschriften zur Geschichte des Unterrichts und der Erziehung bei den deutschen Juden: Von den ältesten Zeiten bis auf Mendelssohn (Amsterdam: Philo Press, 1968), 77. His brother, the Maharal of Prague (c 1512/25-1609), was an even more outspoken opponent. Maharal believed that such codes allowed, even forced, people to make decisions from ignorance and lowered the level of knowledge more generally. He wrote that it was better to decide from the Talmud itself (relying on a collection of decisions allows one to decide without knowing); see ibid., 69.

27 Joseph Davis, "The Reception of the Shulhan 'Arukh and the Formation of Ashkenazic Jewish Identity,” AJS Review 26:2 (2000): 251-76.

28 Ibid., 273; see Isadore Twersky, "Law and Spirituality in the $17^{\text {th }}$ Century: A Case Study in R. Yair Hayyim Bacharach," in Jewish Thought in the Seventeenth Century, eds. Isadore Twersky and Bernard Septimus (Cambridge, MA: Harvard University Center for Jewish Studies, 1987), 447-67, here at 449. Bacharach urged the study of codes (ibid., 452-53).

29 Davis, "The Reception of the Shulhan 'Arukh," 267. 
In early modern German Jewry, dissidence was not merely moralized against; it was also punished, specifically through fines and excommunication (herem). Among the more common forms of dissidence, aside from informing ${ }^{30}$ and apostasy, we find Sabbath desecration (as well as the transgression of other religious laws, such as shaving the beard), ${ }^{31}$ the disruption of prayer or synagogue decorum, ${ }^{32}$ disrespect for the authority of communal officials, ${ }^{33}$ the violation of sumptuary laws, scandalous behavior (including participation in games of chance and violence), ${ }^{34}$ problematic writings, ${ }^{35}$ and inappropriate relations with Christians - either relations that were too intimate or actions that might provoke negative Christian reaction. ${ }^{36}$

The Reformation could provide a sounding-board against which to measure Jewish behavior and religious observance. Josel's famous twentieth-century biographer, Selma Stern, saw Josel as a social critic and social reformer of German Jews who, like the humanists, brought the Jews back to the wellsprings of their history and, like adherents of the devotio moderna, patterned his own conduct and lifestyle after the Pietists of Germany. ${ }^{37}$ Stern attributed to Josel's petition to the Royal Commission the same spirit that animated broadsides and articles of the rebellious peasants of the 1520 s. $^{38}$ Indeed, she saw his "Articles and Reg-

30 Apparently considered the most dangerous infractions. See Yosef Kaplan, "The Place of the Herem in the Sefardic Community of Hamburg during the Seventeenth Century," in Die Sefarden in Hamburg: Zur Geschichte einer Minderheit, part 1, ed. Michael Studemund-Halevy (Hamburg: Buske Verlag 1994): 63-87, here at 72.

31 Including mention in Hamburg of people "careless" or "lacking conscience;" ibid., 77; 81 regarding transgressions against halakah.

32 See also Güdemann, Quellenschriften, 55 ff. for the 1583 Jewish-German book Buch des ewigen Lebens. It is indicated that one should not speak or hear Neuigkeiten said during the Torah reading in the synagogue.

33 Kaplan, “The Place of the Herem," 81.

34 Ibid.

35 Ibid., 72.

36 See statutes from 1685 in: Die Statuten der drei Gemeinden Altona, Hamburg und Wandsbek: Quellen zur Jüdischen Gemeindeorganisation im 17. und 18. Jahrhundert, ed. Heinz Mosche Graupe (Hamburg: Christians Verlag, 1973), for example, “[for every] man or woman, young man or maiden, it is forbidden, on the Sabbath and on holidays to go to drink in a non-Jewish inn. Likewise it is forbidden to visit on Shabbat [a] skittle floor, a comedy, fencing school - with penalty of 4 Rt. Women and girls should generally not go to the opera, not even on weekdays with the same punishment" (86).

37 Selma Stern, Josel of Rosheim: Commander of Jewry in the Holy Roman Empire of the German Nation, trans. Gertrude Hirschler (Philadelphia: Jewish Publication Society of America, 1965 (orig., 1959), xviii.

38 Ibid., 70 -71. 
ulations" as the first large-scale attempt to purge the life of Jews, improve deteriorating social and economic conditions, and facilitate the adjustment to changing social and economic realities. ${ }^{39}$

Various pinkasim (communal ledgers) and communal legislation also addressed these issues. Famously, the important Frankfurt synod of 1603 attempted to formulate German-wide standards of behavior and governing mechanisms. It devised punishments for a variety of transgressors, including Jews who compelled opposing litigants to go to secular courts, ${ }^{40}$ who informed on the community, or who used their wealth or power to press their own advantages; ${ }^{41}$ created centralized courts and tax collection centers; ${ }^{42}$ and attempted to regulate rabbinic jurisdiction ${ }^{43}$ and rabbinic titles, ${ }^{44}$ as well as the publication of books. ${ }^{45}$ of course, earlier, late medieval, German synods had also grappled with some of these and other challenges, and the ordinances of the early seventeenth century synod need to be read in the context of those discussions as well as the Confessional discussions of the later sixteenth century.

The defining and punishment of dissent was a recurrent topic in early modern German Jewish sources. On one hand, such discussions continued late medieval considerations; ${ }^{46}$ on the other, they revealed increased concern with generating and regulating communal norms of behavior, for both internal organization and external accountability. In this sense, the Jewish communities were indeed a part of the early modern territorialization of the state, which itself took even greater interest in the internal boundaries and affairs of the Jewish communities than its late medieval predecessors.

Jewish education in the early modern period similarly maintained important links with previous traditions, all the while evidencing new emphases. In the early modern period, the educational institution of the Talmud Torah became

39 Ibid., 119.

40 Louis Finkelstein, Jewish Self Government in the Middle Ages (New York: The Jewish Theological Seminary of America, 1964), 257.

41 Ibid., 258.

42 Ibid., 259.

43 Ibid., 263. See also Eric Zimmer, Jewish Synods in Germany during the Late Middle Ages (1286-1603) (New York: Yeshiva University, 1978), 140-47 for excerpts from the Frankfurt synod of 1542 that detailed the issue of jurisdiction.

44 Finkelstein, Jewish Self Government in the Middle Ages, 260-61.

45 Ibid., 263.

46 See, for example, the complex community dynamics related to violence within the community, as described in Dean Phillip Bell, "Early Modern Comparative Topics and Emerging Trends," in The Routledge Companion to Jewish History and Historiography, ed. Dean Philipp Bell (London: Routledge, 2019): 207-20, esp. 212-17. 
better structured and more formally organized, serving a broader communal population. ${ }^{47}$ The spread of printing made seminal works more standardized and accessible. Leading rabbinic authorities increasingly promoted a 'proper' order of study. This, along with the possession of certain standard works, such as popular grammars, opened the door to more consistency in Jewish education. Alongside a lament for the dismal Hebrew skills of many Jews, a call for a return to the text and a certain Reformation Biblicism could sometimes be detected among some Jewish writers. ${ }^{48}$ Jews also similarly drew from and imbibed nonJewish literature, thought, and practices. The work of the late sixteenth-century Prague astronomer and historian David Gans, for example, has been seen within the context of contemporary German and Czech chronicles as well as within the context of burgeoning burgher literature in early modern Germany. ${ }^{49}$ According to Mordechai Breuer,

In his low opinion of the rabbinical titularies and hierarchy Gans may have been influenced by the elevation of the lay element in the congregation effected by the Lutheran Reformation, and more particularly by the egalitarianism practiced by the Bohemian Brothers who required their priests to make their living through the work of their own hands. ${ }^{50}$

Early modern German Jewry evinced signs of growing communal organization, despite thinly spread settlement and often small community size. Increasingly, Jews - like their non-Jewish peers - turned to more bureaucratic tools and practices. ${ }^{51}$ Not surprisingly, the early modern period witnessed a growing number of community pinkasim, memorybooks, formal constitutions, community offices, and institutions, such as those for the sick. In some cases, the impetus for communal institutional re-structuring came from the outside, as Christian civic, territorial, or even imperial agents required Jews to adhere to particular codes, policies, or practices.

47 Encyclopedia Judaica, “Jewish Education, Italy.”

48 Though see the Maharal's opposition to Azariah de Rossi (1511-1587), more generally, in Lester A. Segal, Historical Consciousness and Religious Tradition in Azariah de' Rossi's Me'or 'Einayim (Philadelphia: Jewish Publication Society of America, 1989). See also Ben-Sasson, “The Reformation," 303, 307-8, 309.

49 See Bell, "Jewish and Christian Historiography in the Sixteenth Century," 157-58.

50 Mordechai Breuer, "Modernism and Traditionalism in Sixteenth-Century Jewish Historiography: A Study of David Gans' Tzemah David,” in Jewish Thought in the Sixteenth Century, ed. Bernard Dov Cooperman (Cambridge, MA: Harvard University Center for Jewish Studies, 1983): $49-88$, here at 70 . Of course, the shifting of power from rabbinic to lay authorities was hardly new to the Jewish community after the Reformation, though there are some intriguing parallels. 51 See Bell, Jewish Identity in Early Modern Germany. 
Consider the protocol book of Friedberg for the year 1574. According to the document, the rabbi was closely supervised and his powers and duties clearly circumscribed..$^{52}$ In this case, the rabbi was obligated to remain in his position for four years, without residing in another area; the council, for its part, was obligated to refrain from seeking another rabbi during this period. The rabbi in question was not to ostracize/excise or place under the ban any residents in the holy community, or from any of the surrounding area, without the agreement of the council. The council, however, retained the authority to ostracize/excise community members without the agreement of the rabbi. The council was to provide the rabbi twelve Gulden in salary every year, and he was freed from all customary taxes (though not every tax obligation). The rabbi was also to receive one Gulden from each betrothal and a Gulden for the lodging of each student in the yeshivah. Other regulations and agreements were also outlined. Importantly, the rabbi was restricted from making changes in the community's customs without the consent of the community board..$^{53}$

Rabbinic contracts only emerged in the sixteenth century, as did formal processes for selecting a rabbi by a community. ${ }^{54}$ The development, or professionalization, of the rabbinate that began in Germany in the fourteenth century has been placed within the context of social and religious (pastoral) changes that occurred among Jews and Christians after the Black Death. ${ }^{55}$ It has also been seen as part of late medieval, especially fifteenth-century developments in law and university education (in which the rabbinic diploma is paralleled to that of the university doctor). ${ }^{56}$ It has been further compared to the development of city councils, guild structures, and the professionalization of lawyers and physicians in the later Middle Ages. ${ }^{57}$

A comprehensive comparison of these documents and communal contracts made with Christian priests in the late medieval and Reformation period may shed light on early modern German Jewish communal developments and en-

52 Stefan Litt, Protokollbuch und Statuten der Jüdischen Gemeinde Friedberg (16.-18. Jahrhundert) (Friedberg: Bindernagel, 2003), 274-76 (beginning at 74 in the Hebrew).

53 See Simon Schwarzfuchs, A Concise History of the Rabbinate (Oxford: Blackwell, 1993), $19-21$.

54 Ibid., 24.

55 See Simon Schwarzfuchs, "The Making of the Rabbi," in Das aschkenasische Rabbinat: Studien über Glaube und Schicksal, ed. Julius Carlebach (Berlin: Metropol, 1995): 133-40, here at 137; Israel Yuval, "Juristen, Ärzte und Rabbiner: Zum typologischen Vergleich intellektueller Berufsgruppen im Spätmittelalter,” in Das aschkenasische Rabbinat, 119-31, here at 122-3.

56 Schwarzfuchs, "The Making of the Rabbi," 138; see Yuval, "Juristen," and his criticism of Robert Bonfil's model, 124.

57 Ibid., 126 
gagement with the non-Jewish world. Setting aside for the moment their important religious practices and orientations, sixteenth-century Church ordinances grappled with similar concerns to Jewish synods and rabbinic contracts. The 1582 Church ordinance from Nassau-Dillenburg, for example, noted the need for proper recognition and jurisdiction of clergy, and stipulated that the clergy should serve as moral role models. Other contracts specified the moral upbraiding of congregants and citizens. ${ }^{58}$ Contracts for priests set out term limits and a range of salaries and benefits that paralleled those found in rabbinic contracts. ${ }^{59}$ Christian clergy had particular financial responsibilities, ritual tasks (e.g., Mass and baptism), ${ }^{60}$ teaching and supervision of scriptural and doctrinal interpretation, and pastoral duties (i.e., visiting the sick ${ }^{61}$ and the delivery of sermons) that differentiated their contracts from those of appointed rabbis, however. ${ }^{62}$ On the one hand, sixteenth-century German Jewish communal developments mirrored late medieval and Reformation changes in which the community arrogated important authority, and lay leaders could see themselves as encompassing some aspects of sacral power and exercising the ability to appoint and remove clergy.

On the other hand, Christian (even Protestant and Lutheran concerns, as reflected in Luther's own, often changing, notion of ministry) ${ }^{63}$ discussions of sacral authority were, almost by definition, differently focused, drawing as they did from general contemporary concerns as well as specific Christian traditions and innovations. What is more, the context for discussions about the roles and authority of the rabbi and other related issues involved a range of Talmudic materials and prior, late medieval, German Jewish communal discussions and rabbinic responsa.

\section{Conclusions}

The Reformation - particularly in a broad sense that began in the fifteenth century and continued beyond the sixteenth - had a notable impact on Jews and

58 See Saulle Hippenmeyer, Nachbarschaft, Pfarrei und Gemeinde in Graubünden 1400 - 1600: Quellen (Chur: Kommissionsverlag Bündner Monatsblatt, 1997), no. 160.

59 See also Rosi Fuhrmann, Kirche und Dorf: Religiöse Bedürfnisse und kirchliche Stiftung auf dem Lande vor der Reformation (Stuttgart: G. Fischer, 1995), 162, 331-2.

60 Ibid., 179, 205.

61 Ibid., 191.

62 See the table in ibid., 200.

63 Martin Luther, Luther's Works, vol. 40, ed. Helmut T. Lehmann (St. Louis: Concordia Publishing House), “Concerning the Ministry (1523)," 34-6. 
Jewish life. Jews did not live in a vacuum, and their exposure to major issues in the non-Jewish world shaped how they perceived that world and themselves. One need not resort to formal Jewish and Christian dialogue to see that the religious, social, and political discussions of the Reformation era significantly impacted early modern German Jews. In its daily life, in its communal organization, indeed in its educational development and at times even its very language, German Jews absorbed - both consciously and unconsciously - the major shifts in society around them, combining them with changes taking place within their own communities. Reformation-era Jews may have been marginalized, but, as recent discussions of marginalization have taught us, the very act of marginalization places the marginalized in direct conversation with the heart of society.

Jewish developments in the Reformation era - as in every other period ought to be considered in light of the development of interactions with the external world. And yet, it would be a mistake to think that Jews unreflectively adopted what was unfolding around them. As discussions of the rabbinate indicate, while there were indeed significant similarities in the approach to religious functionaries and while the rabbinate was 'professionalized' in some important ways, the foci of the position and its role in a community could be vastly different from that of clergy in Christian society. Jewish discussions of rabbinic authority, therefore, must also be understood within the context of earlier Jewish communal developments and discussions, which drew both from Jewish texts and traditions and their own broader milieux. The notion that Reformation-era Jews were free from rubbish or that they were somehow hermetically separated from the non-Jewish world in which they lived may be safely put to rest. At the same time, however, and, to some extent, countering recent scholarship, one notes that early modern German Jewish society differed from that which surrounded it in important ways. The Reformation affected Jews directly in some ways and less directly in others, and its impact was inflected by Jewish sensibilities and internal concerns - as was true as well for diverse Christian communities across Europe. As a construct, the Reformation is invaluable for framing and grappling with central early modern Jewish developments - for both the ideas and practices that affected Jews and those that lacked resonance because of unique Jewish communal and historical concerns. 
